\title{
Treatment of idiopathic nephrotic syndrome with two steroid dosing regimens - one-year observational study
}

\author{
MAEGORZATA PAŃCZYK-TOMASZEWSKA', PIOTR SKRZYPCZYK' , KACPER MROCZKOWSKI', \\ BEATA LESZCZYŃSKA ${ }^{l}$, MAEGORZATA MIZERSKA-WASIAK ${ }^{l}$
}

${ }^{1}$ Department of Pediatrics and Nephrology, Medical University of Warsaw, Warsaw, Poland

${ }^{2}$ Student Scientific Group at the Department of Pediatrics and Nephrology, Medical University of Warsaw, Warsaw, Poland

\begin{abstract}
Introduction: The aim of the study was to compare the first year of disease in children with idiopathic nephrotic syndrome (INS) treated according to two prednisone dosing regimens: a weight-based schedule $\left(2 \mathrm{mg} / \mathrm{kg} / 24 \mathrm{~h}\right.$ in the $1^{\text {st }}$ month, $2 \mathrm{mg} / \mathrm{kg} / 48 \mathrm{~h}$ in the $2^{\text {nd }}$ month, with dose tapering during the following 4 months), and a body surface area (BSA)-based schedule $\left(60 \mathrm{mg} / \mathrm{m}^{2} / 24 \mathrm{~h}\right.$ in the $1^{\text {st }} \mathrm{month}$, $40 \mathrm{mg} / \mathrm{m}^{2} / 48 \mathrm{~h}$ in the $2^{\text {nd }}$ month, with dose tapering during the following 4 months).

Material and methods: In 2 groups of children treated with weight-and BSA-based regimens (20 patients, $3.13 \pm 1.01$ years, treated in $2010-2013$ and 20 patients, $5.13 \pm 2.86$ years, treated in 2014 2016) clinical and anthropometrical parameters, number of INS relapses, total prednisone dose ( $\mathrm{mg} / \mathrm{kg} /$ year), and steroid adverse effects were compared during the first year of disease.

Results: Children treated with the weight-based steroid regimen received a higher total annual prednisone dose (259.06 $\pm 79.54 \mathrm{vs.} 185.83 \pm 72.67 \mathrm{mg} / \mathrm{kg} / 24 \mathrm{~h}, \mathrm{p}=0.004)$ and had a shorter (though not significantly) period without prednisone $(38.25 \pm 55.83 \mathrm{vs} .75 .90 \pm 73.06$ days, $p=0.062)$ compared to patients treated with the BSA-based regimen. There was no difference in number of relapses between groups $(2.20 \pm 1.64 \mathrm{vs} .1 .60 \pm 1.67, p=0.190)$ but more patients relapsed in the weight-based group (19/20 vs. 13/20, $p=0.044)$. No differences in Z-score values of height, weight, and body mass index (BMI) were observed. No steroid-related adverse events were noted except for arterial hypertension (4/20 vs. 5/20 patients, $p=1.000)$.

Conclusions: The BSA-based regimen of prednisone dosing in children with INS reduces exposure to steroids and risk of relapse, as well as increases days off steroids in the first year compared to the weight-based regimen with a high second-month dose.
\end{abstract}

Key words: children, prednisone, idiopathic nephrotic syndrome, dosing regimen, glucocorticoids.

(Cent J Eur Immunol 2021; 46 (3): 344-350)

\section{Introduction}

Glucocorticoids (GS) have been used in the treatment of nephrotic syndrome (NS) since the 1950s [1]. They were found effective in inducing remission in approximately $90 \%$ of affected children and led to a substantial reduction in mortality (from $40 \%$ to less than $1 \%$ ). On the other hand, GS carry the risk of complications such as arterial hypertension, diabetes, cataract, glaucoma, obesity, immunodeficiency, osteoporosis, and growth deficiency [2]. Despite many years of experience, there is still no established unambiguous treatment regimen of first bout and relapses of NS. Studies are aimed at reducing the number of NS relapses and minimizing GS doses and side effects.
Both duration of the treatment and GS initial dose are matters of discussion. Two-, 3- and 6-month regimens have been used with conflicting data on the optimal treatment span [3, 4], though recent studies [5, 6] and guidelines [7, 8] suggest short treatment duration in the majority of affected children.

Also, the applied prednisone dose is a question of debate. To date, the dose proposed by the International Study of Kidney Diseases in Children (ISKDC) $\left(60 \mathrm{mg} / \mathrm{m}^{2} / 24 \mathrm{~h}\right.$ ) is considered most effective [9]. Worldwide, a dose of prednisone converted into $\mathrm{kg}$, i.e. $2 \mathrm{mg} / \mathrm{kg}$ (maximum $60 \mathrm{mg} / 24 \mathrm{~h}$ ), is also used [9]. Prednisone doses calculated per kilogram of body weight compared to those calculated based on the body surface area are significantly lower in

Correspondence: Piotr Skrzypczyk, MD, PhD, Department of Pediatrics and Nephrology, Medical University of Warsaw, Warsaw, Poland, e-mail: pskrzypczyk@wum.edu.pl

Submitted: 11.02.2021; Accepted: 24.05.2021 
children with a body weight of $<30 \mathrm{~kg}$ [10]. In 2011 Saadeh et al. observed that prednisone underdosing resulting from dosing prescribed according to weight increases the likelihood of frequently relapsing course of NS [11]. Thus, both Kidney Disease Initiative Global Outcome (KDIGO) and the Polish Society for Paediatric Nephrology recommend initial treatment $60 \mathrm{mg} / \mathrm{m}^{2} / 24 \mathrm{~h}$ (not exceeding $60 \mathrm{mg} / 24 \mathrm{~h}$ ) in the first month, $40 \mathrm{mg} / \mathrm{m}^{2} / 48 \mathrm{~h}$ in the following month with a 1-4 month further tapering period $[2,12]$. In our department we used a weight-based regimen until 2013, then we adapted our treatment protocol strictly according to KDIGO recommendations.

The aim of the study was to compare the first year of the disease in children with NS treated according these two regimens: a weight-based schedule (i.e., $2 \mathrm{mg} / \mathrm{kg} / 24 \mathrm{~h}$ in the first month, $2 \mathrm{mg} / \mathrm{kg} / 48 \mathrm{~h}$ in the second month, with gradual dose tapering during the following 4 months), and a body surface area (BSA)-based schedule (i.e. $60 \mathrm{mg} / \mathrm{m}^{2} /$ $24 \mathrm{~h}$ in the first month, $40 \mathrm{mg} / \mathrm{m}^{2} / 48 \mathrm{~h}$ in the second month, with gradual dose tapering during the following 4 months).

\section{Material and methods}

The study group included 40 children ( 28 boys and 12 girls) aged from 1.64 to 11.56 , mean $4.13 \pm 2.34$ years, with the first bout of steroid-sensitive (SS) idiopathic nephrotic syndrome (INS). The patients were divided into two 20-children groups depending on the regimen of treatment.

Data in group I were collected retrospectively, based on medical records from 2010-2013. Group I consisted of 20 children aged from 1.64 to 4.98 years. In this group treatment of the first INS bout was as follows: prednisone $2 \mathrm{mg} / \mathrm{kg} /$ day (not exceeding $60 \mathrm{mg} /$ day) for $1 \mathrm{month}$, $2 \mathrm{mg} / \mathrm{kg} / 48$ hours for 1 month, then reduced gradually for another 4 months. In the treatment of relapses, the same regimen was used. Recurrences of non-nephrotic proteinuria were treated with a daily prednisone in the same dose as previously used on alternate days until the date of resolution of proteinuria +7 days, then the reduction of steroids continued. In this group, a patient weighing $30 \mathrm{~kg}$ with BSA $1 \mathrm{~m}^{2}$ received $4437.5 \mathrm{mg}$, i.e., $147.92 \mathrm{mg} / \mathrm{kg}$ of prednisone as treatment of the first INS bout.

Data in group II were collected prospectively in the years 2014-2016. The group consisted of 20 children aged from 1.77 to 11.56 years. The following regimen of treatment of the first bout of INS was used: prednisone $60 \mathrm{mg} / \mathrm{m}^{2} /$ day (not exceeding $60 \mathrm{mg} /$ day) for $1 \mathrm{month}$, $40 \mathrm{mg} / \mathrm{m}^{2} / 48$ hours for 1 month, with gradual reduction of the dose during the following 4 months. In the treatment of relapses of INS prednisone was used at a dose of: $60 \mathrm{mg} / \mathrm{m}^{2} /$ day (not exceeding $60 \mathrm{mg}$ ) until the day of resolution of proteinuria +3 days, then $40 \mathrm{mg} / \mathrm{m}^{2} / 48$ hours for 4 weeks with further reduction during the following
4 months. In the recurrences of non-nephrotic proteinuria, a daily dose of the previously used prednisone dose every 48 hours was used until the day of resolution of proteinuria +3 days, then the reduction continued. In this group, a patient weighing $30 \mathrm{~kg}$ with BSA $1 \mathrm{~m}^{2}$ received $3620 \mathrm{mg}$, i.e., $120.67 \mathrm{mg} / \mathrm{kg}$ of prednisone as treatment of the first INS bout.

Patients from both groups were observed during the first year of the disease.

The diagnosis of NS was based on proteinuria $>50 \mathrm{mg} / \mathrm{kg} / 24 \mathrm{~h}$, hypoalbuminemia $(\leq 2.5 \mathrm{~g} / \mathrm{dl})$, hyperlipidemia, and edema $[9,10]$. Idiopathic nephrotic syndrome was defined based on exclusion of the following features in a child with NS: age of presentation $<1$ year and $>12$ years, constant erythrocyturia or gross hematuria, arterial hypertension (at presentation), hypocomplementemia, persistent impairment of renal function, and extrarenal manifestations suggesting systemic disease (e.g., arthritis, oral ulcerations). Steroid-sensitiveness was defined as entering remission within 8 weeks of prednisone treatment of INS. Time to remission was defined as the first day of a 3-day period of absent proteinuria in urinalysis in treatment of the first INS bout [2, 12].

Relapse of INS was recognized in case of recurrence of nephrotic range proteinuria ( $>50 \mathrm{mg} / \mathrm{kg} / 24 \mathrm{~h}$ ) usually with hypoalbuminemia $\leq 2.5 \mathrm{~g} / \mathrm{dl}$. Recurrence of non-nephrotic proteinuria was defined as proteinuria $<50 \mathrm{mg} / \mathrm{kg}$ / day without a drop in serum albumin $\leq 2.5 \mathrm{~g} / \mathrm{dl}$. They were together analyzed as relapses of proteinuria $(n)$.

The following parameters were analyzed in the studied children: age at presentation of first INS bout (years), sex, time to remission (days), total annual dose of prednisone $(\mathrm{mg} / \mathrm{kg} / \mathrm{year})$, number of days without prednisone in the first year (days), number of relapsing patients $(n)$, number of relapses of proteinuria $(n)$, and presence of the following side effects of prednisone treatment: arterial hypertension, glaucoma, cataract, and disturbances of glucose metabolism. In addition, in all patients prior to the onset of prednisone treatment, and then after 12 months height $(\mathrm{cm})$, body weight (initial weight was assessed after resolution of edema) (kg), and body mass index (BMI; $\mathrm{kg} / \mathrm{m}^{2}$ ) were evaluated. All anthropometric variables were compared with Polish charts by Palczewska and Niedźwiecka and expressed as Z-scores [13]. Overweight was defined as a BMI Z-score $>1$ and obesity as BMI $>2$ according to World Health Organization (WHO) recommendations.

The results obtained were statistically analyzed using Dell Statistica 13.0 PL (TIBCO Software Inc., Palo Alto, CA, USA). Normality of data sets was established with the Shapiro-Wilk test. All data were presented as mean \pm standard deviation and interquartile range. The differences between normally distributed data were evaluated using Student's $t$-test, and between non-normally distributed data using the Mann-Whitney $U$ test and Wilcoxon test. The number of patients in both groups was compared using 


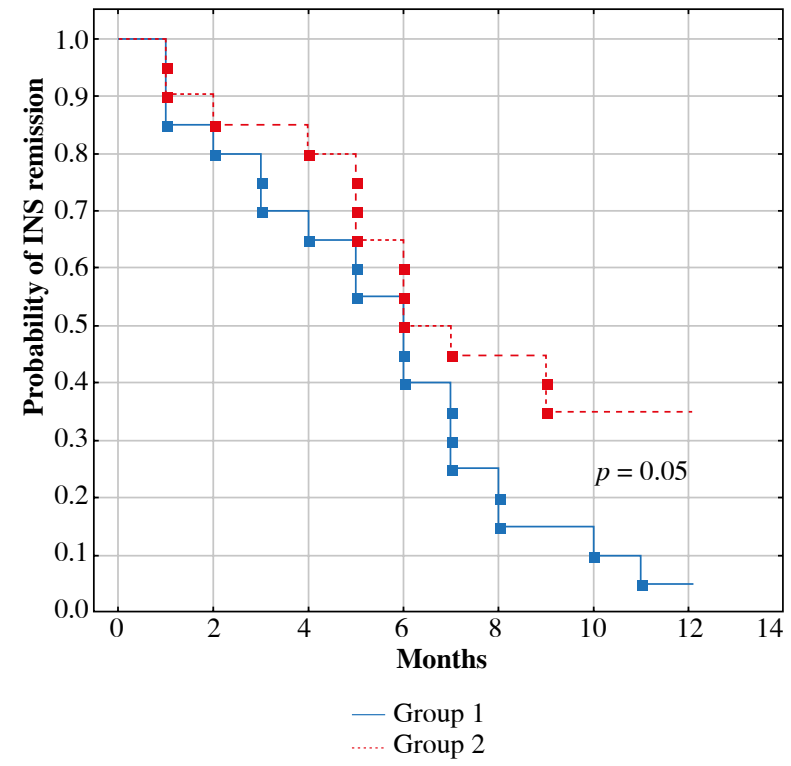

Fig. 1. Risk of idiopathic nephrotic syndrome (INS) relapse in both groups in one-year observation

Fisher's exact test. The relations between quantitative variables were analyzed using Pearson correlation or Spearman's rank correlation, when appropriate. Kaplan-Meier analysis and the log-rank test were used to compare oneyear risk of INS relapse in two groups. A $p$-value $<0.05$ was considered statistically significant.

\section{Results}

The clinical data and course of INS during the first year of follow-up in both groups were shown in Table 1. Patients in the first group (treated in the period 20102013) were significantly younger compared to patients in the second group (treated in the period 2014-2016). There was no difference between the groups in time to relapse or in number of relapses per year, but the second group was characterized by a lower number of relapsing patients, a lower total annual prednisone dose and a non-significantly higher number of days without prednisone. The log-rank test revealed higher probability of INS relapse in one-year observation in the first group ( $p=0.05)$ (Fig. 1).

In group I arterial hypertension appeared soon after treatment initiation in one child and resolved after 5 months. In addition, arterial hypertension was observed in 3 other children from this group at 12 months of follow-up. In group II, arterial hypertension started in 4 children at the beginning of the treatment; after 12 months it was still present in one child and appeared in another child. There was no significant difference in number of hypertensive patients between the groups $(4 / 20$ vs. $5 / 20, p=1.000)$. Ocular complications in the form of cataract or glaucoma were not found in any patients. Also, renal function was normal in all children at the beginning of the treatment and after 12 months. No glucose metabolism disturbances were observed in any of the analyzed children.

Anthropometric data in children with idiopathic nephrotic syndrome are shown in Table 2. Patients from group II were taller than patients from group I at the beginning of observation and after 12 years. The groups did not differ significantly in any other analyzed anthropometric variables. Before initiation of the steroid treatment there were 3 overweight and 3 obese children in group I, and one overweight and one obese child in the second group. After a year, these numbers increased to 5 overweight and 6 obese children in group I, and 5 overweight and 1 obese patient in the second group.

In the first group total annual prednisone dose $(\mathrm{mg} / \mathrm{kg} /$ year) correlated negatively with annual change in height Z-score $(r=-0.520, p=0.018)$ and positively with annual change in BMI Z-score $(r=0.543, p=0.013)$. Also, number of days without prednisone correlated negatively

Table 1. Clinical data and course of idiopathic nephrotic syndrome in studied children

\begin{tabular}{|c|c|c|c|}
\hline Variable & Group I & Group II & $\boldsymbol{P}$ \\
\hline Number of patients & 20 & 20 & - \\
\hline Boys/girls $(n)$ & $16 / 4$ & $12 / 8$ & 0.301 \\
\hline Age (years) & $\begin{array}{l}3.13 \pm 1.01 \\
(2.20-3.96)\end{array}$ & $\begin{array}{l}5.13 \pm 2.86 \\
(2.86-7.01)\end{array}$ & 0.015 \\
\hline Time to remission (days) & $\begin{array}{c}10.20 \pm 4.86 \\
\quad(7-12)\end{array}$ & $\begin{array}{c}8.80 \pm 2.97 \\
(7-11)\end{array}$ & 0.508 \\
\hline Total annual prednisone dose (mg/kg/year) & $\begin{array}{c}259.06 \pm 79.54 \\
(221.13-302.88)\end{array}$ & $\begin{array}{c}185.83 \pm 72.67 \\
(127.42-227.50)\end{array}$ & 0.004 \\
\hline Days without prednisone during first year of the disease (days) & $\begin{array}{c}38.25 \pm 55.83 \\
(0-63)\end{array}$ & $\begin{array}{c}75.90 \pm 73.06 \\
(3-158)\end{array}$ & 0.062 \\
\hline Number of patients with relapses of proteinuria $(n)$ & $19(95 \%)$ & $13(65 \%)$ & 0.044 \\
\hline Total number of relapses $(n)$ & $\begin{array}{c}2.20 \pm 1.64 \\
(1-3)\end{array}$ & $\begin{array}{c}1.60 \pm 1.67 \\
(0-3)\end{array}$ & 0.190 \\
\hline
\end{tabular}


with BMI after 12 months $(r=-0.570, p=0.009)$, BMI Z-score after 12 months $(r=-0.57, p=0.011)$, increase in BMI $(r=-0.617, p=0.004)$, and increase in BMI Z-score $(r=-0.636, p=0.003)$. Total number of proteinuria relapses correlated positively with increase in BMI $(r=0.456$, $p=0.043)$ and BMI Z-score $(r=0.387, p=0.014)$. In the second group total annual prednisone dose $(\mathrm{mg} / \mathrm{kg} /$ year) correlated negatively with annual change in height $\mathrm{Z}$-score $(r=-0.524, p=0.018)$ and positively with annual change in BMI Z-score $(r=0.617, p=0.004)$. Total number of proteinuria relapses correlated positively with weight $Z$-score after 12 months and negatively with annual increase in height $\mathrm{Z}$-score $(r=-0.597, p=0.005)$.

\section{Discussion}

Our study focused on differences in clinical outcome between children with INS treated with two regimens of prednisone dosage. Analysis of our results revealed that the children treated with prednisone dosed for body surface area were found to be significantly less exposed to glucocorticoids. Nevertheless, this regimen did not influence the number of INS relapses or increase in body weight or BMI. Of note, in the weight-based regimen the second-month dose was substantially higher compared to the BSA-based regimen, which might have influenced the final conclusions.

Idiopathic nephrotic syndrome is the most common glomerular disease in children, with the vast majority of patients responding well to corticosteroids. The goal of the treatment is to achieve early remission, decrease the rate of relapses and reduce the cumulative exposure to steroids. Thus, the optimal duration and dosage of corticosteroids remain unsolved, with only a few randomized trials performed on this topic $[5,6,14,15]$. Table 3 shows a summary of treatment regimens recommended by different guidelines $[2,12]$. Although originally the ISKDC recommended prednisone dosage adjusted for BSA $\left(60 \mathrm{mg} / \mathrm{m}^{2} /\right.$ 24 h) [9], several studies of children with INS recommended an initial starting dosage of $2 \mathrm{mg} / \mathrm{kg}$ body weight per day [16-18]. Also, many authors and guidelines recommended either a weight-based or a BSA-based protocol, assuming them to be equivalent $[2,12]$.

The response to GS in patients with immune-mediated diseases is dose dependent, though optimal dosage to induce remission in INS is unknown. Also, the exact mechanism of action of GS in INS is not clear yet and may be multifactorial, involving both immunological and non-immunological actions [19, 20]. Experimental data suggest that glomerular podocytes may be a direct target of GS, as human podocytes express glucocorticoid receptors. The beneficial effect of GS might be due to direct protection of podocytes from injury and promotion of podocyte repair via upregulation of expression of the nephrin gene and stabilization of actin filaments
Table 2. Anthropometric data in children with idiopathic nephrotic syndrome

\begin{tabular}{|c|c|c|c|}
\hline \multirow[t]{2}{*}{ Variable } & \multicolumn{2}{|c|}{ Patient group } & \multirow[t]{2}{*}{$P$} \\
\hline & Group I & Group II & \\
\hline Height $0(\mathrm{~cm})$ & $\begin{array}{c}97.02 \pm 8.36 \\
\quad(91-104)\end{array}$ & $\begin{array}{c}107.93 \pm 16.06 \\
(94-122)\end{array}$ & 0.010 \\
\hline Height $0 \mathrm{Z}$-score & $\begin{array}{c}0.41 \pm 1.42 \\
(-0.43-1.33)\end{array}$ & $\begin{array}{l}-0.03 \pm 0.99 \\
(-0.55-0.54)\end{array}$ & 0.262 \\
\hline Weight $0(\mathrm{~kg})$ & $\begin{array}{c}16.07 \pm 3.24 \\
(14.10-17.95)\end{array}$ & $\begin{array}{l}20.66 \pm 11.17 \\
(14.25-21.45)\end{array}$ & 0.310 \\
\hline Weight $0 \mathrm{Z}$-score & $\begin{array}{c}0.60 \pm 1.38 \\
(-0.40-1.58)\end{array}$ & $\begin{array}{c}0.09 \pm 0.81 \\
(-0.60-0.74)\end{array}$ & 0.159 \\
\hline BMI $0\left(\mathrm{~kg} / \mathrm{m}^{2}\right)$ & $\begin{array}{c}16.97 \pm 1.94 \\
(15.94-17.96)\end{array}$ & $\begin{array}{c}16.70 \pm 3.16 \\
(14.67-16.82)\end{array}$ & 0.229 \\
\hline BMI 0 Z-score & $\begin{array}{c}0.55 \pm 1.23 \\
(-0.21-1.45)\end{array}$ & $\begin{array}{c}0.12 \pm 0.98 \\
(-0.51-0.84)\end{array}$ & 0.236 \\
\hline Height $12(\mathrm{~cm})$ & $\begin{array}{c}104.80 \pm 8.33 \\
(100-111)\end{array}$ & $\begin{array}{c}114.88 \pm 15.93 \\
(101-126)\end{array}$ & 0.017 \\
\hline $\begin{array}{l}\text { Height } 12 \\
\text { Z-score }\end{array}$ & $\begin{array}{c}0.44 \pm 1.18 \\
(-0.09-1.06) \\
\end{array}$ & $\begin{array}{l}-0.01 \pm 0.87 \\
(-0.46-0.43)\end{array}$ & 0.176 \\
\hline Weight $12(\mathrm{~kg})$ & $\begin{array}{c}19.44 \pm 4.39 \\
(16.50-20.75)\end{array}$ & $\begin{array}{l}24.83 \pm 13.55 \\
(16.90-26.33)\end{array}$ & 0.344 \\
\hline $\begin{array}{l}\text { Weight } 12 \\
\text { Z-score }\end{array}$ & $\begin{array}{c}0.98 \pm 1.24 \\
(0.08-1.76)\end{array}$ & $\begin{array}{c}0.46 \pm 0.70 \\
(-0.03-0.96)\end{array}$ & 0.116 \\
\hline BMI $12\left(\mathrm{~kg} / \mathrm{m}^{2}\right)$ & $\begin{array}{c}17.54 \pm 2.28 \\
(15.98-19.05)\end{array}$ & $\begin{array}{c}17.66 \pm 3.71 \\
(15.64-17.74)\end{array}$ & 0.457 \\
\hline BMI 12 Z-score & $\begin{array}{c}1.10 \pm 1.23 \\
(0.21-2.07) \\
\end{array}$ & $\begin{array}{l}0.59 \pm 1.01 \\
(0.07-1.22)\end{array}$ & 0.160 \\
\hline $\begin{array}{l}\Delta 0-12 \text { height } \\
(\mathrm{cm})\end{array}$ & $\begin{array}{l}7.79 \pm 4.09 \\
(5.0-10.0)\end{array}$ & $\begin{array}{c}6.95 \pm 2.41 \\
(5.0-9.0)\end{array}$ & 0.776 \\
\hline $\begin{array}{l}\Delta 0 \text { - } 12 \text { height } \\
\text { Z-score }\end{array}$ & $\begin{array}{c}0.03 \pm 1.05 \\
(-0.54-0.53)\end{array}$ & $\begin{array}{c}0.02 \pm 0.53 \\
(-0.40-0.31)\end{array}$ & 0.818 \\
\hline $\begin{array}{l}\Delta 0-12 \text { Weight } \\
(\mathrm{kg}) \\
\Delta 0-12 \text { Weight } \\
\text { Z-score }\end{array}$ & $\begin{array}{c}3.37 \pm 2.86 \\
(1.90-3.80) \\
0.37 \pm 1.01 \\
(-0.35-0.79)\end{array}$ & $\begin{array}{c}4.18 \pm 2.89 \\
(2.20-5.80) \\
0.37 \pm 0.47 \\
(0.05-0.63)\end{array}$ & 0.449 \\
\hline $\begin{array}{l}\Delta 0-12 \text { BMI } \\
\left(\mathrm{kg} / \mathrm{m}^{2}\right) \\
\Delta 0-12 \text { BMI } \\
\text { Z-score }\end{array}$ & $\begin{array}{c}0.57 \pm 1.84 \\
(-0.63-1.17) \\
0.55 \pm 1.14 \\
(-0.35-1.11)\end{array}$ & $\begin{array}{c}0.97 \pm 1.59 \\
(-0.11-1.07) \\
0.47 \pm 0.71 \\
(-0.03-0.69)\end{array}$ & 0.543 \\
\hline
\end{tabular}

BMI-body mass index

and prevention of apoptosis [21,22]. Doses necessary to stabilize podocyte cytoskeleton may be even lower than $2 \mathrm{mg} / \mathrm{kg} / 24 \mathrm{~h}$, as suggested by Mehls and Hoyer [23]. On the other hand, there are data suggesting that an increased cumulative dose during treatment of the first bout induces longer and more stable remission - probably influencing lymphocyte activity $[19,20]$.

Feber in 2009 found that the dosage of prednisone at $2 \mathrm{mg} / \mathrm{kg}$ per day versus $60 \mathrm{mg} / \mathrm{m}^{2}$ per day is significantly smaller for patients with weights $<30 \mathrm{~kg}$. In the study by Feber the median dose per kilogram reached only $85 \%$ of the dose calculated per square meter and $91 \%$ of patients had been given a lower dose (ratio $<1.0$ ) if the prednisone dose had been calculated as $2 \mathrm{mg} / \mathrm{kg} / 24 \mathrm{~h}$ [10]. To 
Table 3. Summary of selected recommendations of treatment of first bout and relapse of idiopathic nephrotic syndrome in children

\begin{tabular}{|c|c|c|}
\hline Recommendations & First bout & Relapse \\
\hline $\begin{array}{l}\text { International Study of Kidney } \\
\text { Disease in Children } 1978 \text { [9] }\end{array}$ & $\begin{array}{l}\text { Prednisone } 60 \mathrm{mg} / \mathrm{m}^{2} / 24 \mathrm{~h} \text { for } 4 \text { weeks, followed by } \\
40 \mathrm{mg} / \mathrm{m}^{2} / 48 \mathrm{~h} \text { for } 4 \text { weeks }\end{array}$ & $\begin{array}{l}\text { Prednisone } 60 \mathrm{mg} / \mathrm{m}^{2} / 24 \mathrm{~h} \text { until negative urine, } \\
\text { followed by a single dose of } 40 \mathrm{mg} / \mathrm{m}^{2} / 48 \mathrm{~h}\end{array}$ \\
\hline $\begin{array}{l}\text { KDIGO Clinical } \\
\text { Practice Guideline for } \\
\text { Glomerulonephritis } 2012 \text { [2] }\end{array}$ & $\begin{array}{l}\text { Prednisone } 60 \mathrm{mg} / \mathrm{m}^{2} / 24 \mathrm{~h} \text { or } 2 \mathrm{mg} / \mathrm{kg} / 24 \mathrm{~h} \text { (max. } 60 \mathrm{mg} \text { ) } \\
\text { in a single dose for } 4-6 \text { weeks, followed by a single } \\
\text { dose of } 40 \mathrm{mg} / \mathrm{m}^{2} / 48 \mathrm{~h} \text { or } 1.5 \mathrm{mg} / \mathrm{kg} / 24 \mathrm{~h} \text { (max. } 40 \mathrm{mg} \text { ) } \\
\text { for } 4-6 \text { weeks. Thereafter prednisone dose is gradually } \\
\text { tapered. Total duration of therapy }-12-24 \text { weeks }\end{array}$ & $\begin{array}{c}\text { Prednisone } 60 \mathrm{mg} / \mathrm{m}^{2} / 24 \mathrm{~h} \text { or } 2 \mathrm{mg} / \mathrm{kg} / 24 \mathrm{~h}(\mathrm{max} \text {. } \\
60 \mathrm{mg}) \text { in a single dose until negative urine for } \\
3 \text { days, followed by a single dose of } 40 \mathrm{mg} / \mathrm{m}^{2} / \\
48 \mathrm{~h} \text { or } 1.5 \mathrm{mg} / \mathrm{kg} / 48 \mathrm{~h}(\max .40 \mathrm{mg}) \text { for at least } \\
4 \text { weeks }\end{array}$ \\
\hline $\begin{array}{l}\text { Canadian Society of } \\
\text { Nephrology Commentary } \\
\text { on the } 2012 \text { KDIGO } \\
\text { clinical practice guideline } \\
\text { for glomerulonephritis: } \\
\text { management of nephrotic } \\
\text { syndrome in children } 2014 \text { [26] }\end{array}$ & $\begin{array}{l}\text { Prednisone } 60 \mathrm{mg} / \mathrm{m}^{2} / 24 \mathrm{~h} \text { or } 2 \mathrm{mg} / \mathrm{kg} / 24 \mathrm{~h} \text { (max. } 60 \mathrm{mg} \text { ) } \\
\text { in a single dose for } 4-6 \text { weeks, followed by a single } \\
\text { dose of } 40 \mathrm{mg} / \mathrm{m}^{2} / 48 \mathrm{~h} \text { or } 1.5 \mathrm{mg} / \mathrm{kg} / 24 \mathrm{~h} \text { (max. } 40 \mathrm{mg} \text { ) } \\
\text { for } 4-6 \text { weeks. Thereafter prednisone dose is gradually } \\
\text { tapered. Total duration of therapy - } 12-24 \text { weeks. } \\
\text { Most patients should be treated for } 12 \text { weeks }\end{array}$ & $\begin{array}{l}\text { Prednisone } 60 \mathrm{mg} / \mathrm{m}^{2} / 24 \mathrm{~h} \text { or } 2 \mathrm{mg} / \mathrm{kg} / 24 \mathrm{~h}(\mathrm{max} . \\
60 \mathrm{mg}) \text { in a single dose until negative urine for } \\
3 \text { days, followed by a single dose of } 40 \mathrm{mg} / \mathrm{m}^{2} / \\
48 \mathrm{~h} \text { or } 1.5 \mathrm{mg} / \mathrm{kg} / 48 \mathrm{~h}(\max .40 \mathrm{mg}) \text { for at least } \\
4 \text { weeks }\end{array}$ \\
\hline $\begin{array}{l}\text { Recommendations of Polish } \\
\text { Society for Paediatric } \\
\text { Nephrology } \\
2015 \text { [12] }\end{array}$ & $\begin{array}{l}\text { Prednisone } 60 \mathrm{mg} / \mathrm{m}^{2} / 24 \mathrm{~h} \text { or } 2 \mathrm{mg} / \mathrm{kg} / 24 \mathrm{~h} \text { (max. } 60 \\
\mathrm{mg} \text { ) in a single dose for } 4-6 \text { weeks, followed by a single } \\
\text { dose of } 40 \mathrm{mg} / \mathrm{m}^{2} / 48 \mathrm{~h} \text { or } 1.5 \mathrm{mg} / \mathrm{kg} / 24 \mathrm{~h} \text { (max. } 40 \mathrm{mg} \text { ) } \\
\text { for } 4-6 \text { weeks. Thereafter prednisone dose is gradually } \\
\text { tapered. Total duration of therapy }-24 \text { weeks }\end{array}$ & $\begin{array}{c}\text { Prednisone } 60 \mathrm{mg} / \mathrm{m}^{2} / 24 \mathrm{~h} \text { or } 2 \mathrm{mg} / \mathrm{kg} / 24 \mathrm{~h} \text { (max. } \\
60 \mathrm{mg} \text { ) in a single dose until negative urine for } 3 \\
\text { days, followed by a single dose of } 40 \mathrm{mg} / \mathrm{m}^{2} / 48 \\
\mathrm{~h} \text { or } 1.5 \mathrm{mg} / \mathrm{kg} / 48 \mathrm{~h} \text { (max. } 40 \mathrm{mg} \text { ) for } 4 \text { weeks. } \\
\text { Thereafter prednisone dose is gradually tapered } \\
\text { during } 4 \text { weeks }\end{array}$ \\
\hline $\begin{array}{l}\text { Recommendations of the } \\
\text { Italian Society for Pediatric } \\
\text { Nephrology } 2017 \text { [7] }\end{array}$ & $\begin{array}{l}\text { Prednisone } 60 \mathrm{mg} / \mathrm{m}^{2} / 24 \mathrm{~h} \text { (max. } 60 \mathrm{mg} \text { ) in a single } \\
\text { dose or divided into } 2 \text { doses for } 6 \text { weeks, followed by } \\
\text { a single dose of } 40 \mathrm{mg} / \mathrm{m}^{2} / 48 \mathrm{~h}(\mathrm{max} .40 \mathrm{mg} \text { ) for } \\
6 \text { weeks. Total duration of therapy }-12 \text { weeks }\end{array}$ & $\begin{array}{l}\text { Prednisone } 60 \mathrm{mg} / \mathrm{m}^{2} / 24 \mathrm{~h}(\mathrm{max} .60 \mathrm{mg}) \text { in } \\
\text { a single dose or divided into } 2 \text { doses until negative } \\
\text { urine for } 5 \text { days, followed by a single dose of } \\
40 \mathrm{mg} / \mathrm{m}^{2} / 48 \mathrm{~h}(\max .40 \mathrm{mg}) \text { for } 4 \text { weeks }\end{array}$ \\
\hline $\begin{array}{l}\text { Current British practice } \\
\text { (according to PREDNOS } \\
\text { protocol) } 2019 \text { [6] }\end{array}$ & $\begin{array}{l}\text { Prednisolone } 60 \mathrm{mg} / \mathrm{m}^{2} / 24 \mathrm{~h}(\max .60 \mathrm{mg}) \text { for } 4 \text { weeks, } \\
\text { followed by } 40 \mathrm{mg} / \mathrm{m}^{2} / 48 \mathrm{~h}(\max .40 \mathrm{mg}) \text { for } 4 \text { weeks }\end{array}$ & $\begin{array}{c}\text { Prednisone } 60 \mathrm{mg} / \mathrm{m}^{2} / 24 \mathrm{~h} \text { (max. } 60 \mathrm{mg} \text { ) until } \\
\text { negative urine for } 3 \text { days, followed by } 40 \mathrm{mg} / \mathrm{m}^{2} / \\
48 \mathrm{~h} \text { (max. } 40 \mathrm{mg} \text { ) for } 1 \text { week, then taper by } 10 \mathrm{mg} / \\
\mathrm{m}^{2} / \text { day per week to complete a total of } 4 \text { weeks }\end{array}$ \\
\hline $\begin{array}{l}\text { Management of idiopathic } \\
\text { childhood nephrotic } \\
\text { syndrome in Sub-Saharan } \\
\text { Africa: Ibadan consensus } \\
\text { statement } 2021 \text { [8] }\end{array}$ & $\begin{array}{l}\text { Prednisone } 60 \mathrm{mg} / \mathrm{m}^{2} / 24 \mathrm{~h} \text { (max. } 60 \mathrm{mg} \text { ) in a single } \\
\text { dose for } 6 \text { weeks, followed by a single dose of } \\
40 \mathrm{mg} / \mathrm{m}^{2} / 48 \mathrm{~h} \text { (max. } 40 \mathrm{mg} \text { ) for } 6 \text { weeks. Thereafter } \\
\text { prednisone dose is tapered at the rate of } 10 \mathrm{mg} / \mathrm{m}^{2} / \\
\text { week to } 5 \mathrm{mg} \text { on alternate days. The dose of prednisone } \\
\text { should be discontinued once tapered down to } 5 \mathrm{mg} \text { on } \\
\text { alternate days. Total duration of therapy - } 16 \text { weeks }\end{array}$ & $\begin{array}{c}\text { Prednisone } 60 \mathrm{mg} / \mathrm{m}^{2} / 24 \mathrm{~h}(\mathrm{max} .60 \mathrm{mg}) \text { in } \\
\text { a single dose or divided into } 2 \text { doses until negative } \\
\text { urine for } 3 \text { days, followed by a single dose of } \\
40 \mathrm{mg} / \mathrm{m}^{2} / 48 \mathrm{~h}(\mathrm{max} .40 \mathrm{mg}) \text { for } 1 \text { week, then } \\
\text { taper by } 10 \mathrm{mg} / \mathrm{m}^{2} / \text { day per week to complete } \\
\text { a total of } 4 \text { weeks }\end{array}$ \\
\hline
\end{tabular}

reveal potential clinical significance of these calculations, Saadeh et al. analyzed retrospectively 56 children with an initial bout of INS treated with a weight-based regimen. The authors found that the underdosing percentage (defined as the difference between the BSA-based and the body weight-based dose) was significantly higher in those who became later frequent relapsers $(16.6 \pm 7.9 \%)$ than in infrequent relapsers $(8.7 \pm 9.8 \%)(p=0.03)$. The underdosing percentage did not influence the initial response rate. The authors concluded that a higher initial dose could probably decrease the risk of further relapses, the need for repeated corticosteroid courses, and the need for the addition of other immunosuppressive drugs [11].

There are two prospective randomized Indian trials comparing outcomes in patients treated with these two regimens. Raman et al. compared 50 children treated with a weight-based and 50 children treated with a BSA-based protocol. The groups did not differ in terms of time to remission and relapse rate, but patients treated with the BSA-based regimen had a higher cumulative GS dose and higher incidence of hypertension [15]. Basu et al. analyzed 60 children in a randomized controlled study (first episode or relapse in infrequent relapsers). The authors also found that the weight-based regimen led to a significantly lower total cumulative steroid dose and lower number of adverse events without a difference in the 6-month relapse-free survival rate [24].

In contrast, our study produced opposite results in terms of the total GS dose. In our center, we used a prednisone dosing regimen in the $2^{\text {nd }}$ month of $2 \mathrm{mg} / \mathrm{kg} / 48 \mathrm{~h}$, while in most recommendations and in the work of Basu and Raman, the prednisone/prednisolone dose in the 
$2^{\text {nd }}$ month was $1.5 \mathrm{mg} / \mathrm{kg} / 24 \mathrm{~h}[2,9,15,24]$. We think that this difference may have significantly affected the results. Hence, the conclusions of our work are different from the works of the mentioned authors. In addition, the Indian authors excluded patients with BSA $>1 \mathrm{~m}^{2}$ and body weight $>30 \mathrm{~kg}$. By contrast, in our cohort there were $3(7.5 \%)$ patients with BSA $>1 \mathrm{~m}^{2}$ and/or body weight $>30 \mathrm{~kg}$. Of note, Italian authors proposed a simple equation (prednisone dose $-2 \mathrm{mg} / \mathrm{kg}+8 \mathrm{mg}$ ) to estimate BSA-directed dosage from the patient's body weight [25].

Corticosteroids have well-known metabolic side effects. High-dose and long-term therapy leads to growth retardation, central obesity, osteoporosis, cataract, and glaucoma. Side effects of systemic corticosteroids are dose- and time-dependent $[20,26]$. In our cohort we did not observe any serious side effects except for arterial hypertension and increase in body weight. In both groups we observed a significant association between total amount of GS administered and increase in weight, BMI, as well as a negative impact on growth rate. A similar dose-dependent impact of GS on anthropometric parameters was found by other authors $[27,28]$. The groups did not differ in mean numbers of relapses, but group II was characterized by a significantly lower dose of prednisone, a lower number of relapsing patients and a non-significantly longer period off steroids. Thus, we are deeply convinced that the therapy regimen currently used by us is favorable compared to the old one.

The study has some limitations including the small number of patients in both groups, non-randomized study design and mixed (retrospective and prospective) protocol, and the significant difference in age between the groups, which could have influenced the results. Of note, the higher dose in the second month ( $2 \mathrm{mg} / \mathrm{kg} / 48 \mathrm{~h}$ ) compared to most weightbased regimens and studies (i.e., $1.5 \mathrm{mg} / \mathrm{kg} / 48 \mathrm{~h}$ ) may have had the most significant effect on the final difference in dose and outcome in the two groups. We also did not perform bone density analysis in the studied group. Further studies are necessary to reveal the best possible therapy protocol for the first bout of idiopathic nephrotic syndrome.

\section{Conclusions}

The body surface area-based regimen of prednisone dosing in children with idiopathic nephrotic syndrome reduces exposure to steroids and risk of relapse, as well as increases days off steroids in the first year of the disease compared to a weight-based regimen with a high second-month dose.

\section{Acknowledgements}

This study is dedicated to the memory of Doctor Elżbieta Kuźma-Mroczkowska.

The authors declare no conflict of interest.

\section{References}

1. Goodman HC, Baxter JH (1957): The nephrotic syndrome; clinical observations on therapy with prednisone and other steroids. J Am Med Assoc 165: 1798-1808.

2. KDIGO (2012): KDIGO Clinical practice guideline for glomerulonephritis. Kidney Int Suppl (2012) 2: 139-274.

3. Hahn D, Hodson EM, Willis NS, et al. (2015): Corticosteroid therapy for nephrotic syndrome in children. Cochrane Database Syst Rev 2015: Cd001533.

4. Sinha A, Saha A, Kumar M, et al. (2015): Extending initial prednisolone treatment in a randomized control trial from 3 to 6 months did not significantly influence the course of illness in children with steroid-sensitive nephrotic syndrome. Kidney Int 87: 217-224.

5. Yoshikawa N, Nakanishi K, Sako M, et al. (2015): A multicenter randomized trial indicates initial prednisolone treatment for childhood nephrotic syndrome for two months is not inferior to six-month treatment. Kidney Int 87: 225-232.

6. Webb NJ, Woolley RL, Lambe T, et al. (2019): Sixteen-week versus standard eight-week prednisolone therapy for childhood nephrotic syndrome: the PREDNOS RCT. Health Technol Assess 23: 1-108.

7. Pasini A, Benetti E, Conti G, et al. (2017): The Italian Society for Pediatric Nephrology (SINePe) consensus document on the management of nephrotic syndrome in children: Part I - Diagnosis and treatment of the first episode and the first relapse. Ital J Pediatr 43: 41.

8. Esezobor C, Ademola AD, Adetunji AE, et al. (2021): Management of idiopathic childhood nephrotic syndrome in sub-Saharan Africa: Ibadan consensus statement. Kidney Int 99: 59-67.

9. ISKDC (1978): Nephrotic syndrome in children: prediction of histopathology from clinical and laboratory characteristics at time of diagnosis. A report of the International Study of Kidney Disease in Children. Kidney Int 13: 159-165.

10. Feber J, Al-Matrafi J, Farhadi E, et al. (2009): Prednisone dosing per body weight or body surface area in children with nephrotic syndrome: is it equivalent? Pediatr Nephrol 24: 1027-1031.

11. Saadeh SA, Baracco R, Jain A, et al. (2011): Weight or body surface area dosing of steroids in nephrotic syndrome: is there an outcome difference? Pediatr Nephrol 26: 2167-2171.

12. Ziółkowska H, Grenda R, Musiał K, et al. (2015): Recommendations of Polish Society Paediatric Nephrology for the management of the child with nephrotic syndrome. Forum Nefrologiczne 8: 238-256.

13. Palczewska I, Niedźwiecka Z (2001): Indicators of the somatic development of Warsaw children and the young. Med Development Age 2: 18-118.

14. Hiraoka M, Tsukahara H, Matsubara K, et al. (2003): A randomized study of two long-course prednisolone regimens for nephrotic syndrome in children. Am J Kidney Dis 41: 11551162.

15. Raman V, Krishnamurthy S, Harichandrakumar KT (2016): Body weight-based prednisolone versus body surface area-based prednisolone regimen for induction of remission in children with nephrotic syndrome: a randomized, open-label, equivalence clinical trial. Pediatr Nephrol 31: 595-604.

16. Bagga A, Ali U, Banerjee S, et al. (2008): Management of steroid sensitive nephrotic syndrome: revised guidelines. Indian Pediatr 45: 203-214.

17. Bagga A, Hari P, Srivastava RN (1999): Prolonged versus standard prednisolone therapy for initial episode of nephrotic syndrome. Pediatr Nephrol 13: 824-827. 
18. Ksiazek J, Wyszyńska T (1995): Short versus long initial prednisone treatment in steroid-sensitive nephrotic syndrome in children. Acta Paediatr 84: 889-893.

19. Hosseiniyan Khatibi SM, Ardalan M, Abediazar S, et al. (2020): The impact of steroids on the injured podocytes in nephrotic syndrome. J Steroid Biochem Mol Biol 196: 105490.

20. Schijvens AM, Ter Heine R, de Wildt SN, et al. (2019): Pharmacology and pharmacogenetics of prednisone and prednisolone in patients with nephrotic syndrome. Pediatr Nephrol 34: 389-403.

21. Wada T, Pippin JW, Marshall CB, et al. (2005): Dexamethasone prevents podocyte apoptosis induced by puromycin aminonucleoside: role of p53 and Bcl-2-related family proteins. J Am Soc Nephrol 16: 2615-2625.

22. Xing CY, Saleem MA, Coward RJ, et al. (2006): Direct effects of dexamethasone on human podocytes. Kidney Int 70: 1038-1045.

23. Mehls O, Hoyer PF (2011): Dosing of glucocorticosteroids in nephrotic syndrome. Pediatr Nephrol 26: 2095-2098.

24. Basu B, Bhattacharyya S, Barua S, et al. (2020): Efficacy of body weight vs body surface area-based prednisolone regimen in nephrotic syndrome. Clin Exp Nephrol 24: 622-629.

25. Emma F, Montini G,Gargiulo A (2019): Equations to estimate prednisone dose using body weight. Pediatr Nephrol 34: 685688.

26. Samuel S, Bitzan M, Zappitelli M, et al. (2014): Canadian Society of Nephrology Commentary on the 2012 KDIGO clinical practice guideline for glomerulonephritis: management of nephrotic syndrome in children. Am J Kidney Dis 63: 354-362.

27. Valavi E, Aminzadeh M, Amouri P, et al. (2020): Effect of prednisolone on linear growth in children with nephrotic syndrome. J Pediatr (Rio J) 96: 117-124.

28. Foster BJ, Shults J, Zemel BS, et al. (2004): Interactions between growth and body composition in children treated with high-dose chronic glucocorticoids. Am J Clin Nutr 80: 1334-1341. 